\title{
A digitalizáció helyzete a magyar élelmiszer-feldolgozó ágazatban
}

\section{The situation of Digitization in the Hungarian Food Processing Industry}

\author{
A. S. DEBRENTI ${ }^{1}$ \\ ${ }^{1}$ Debreceni Egyetem, Gazdaságtudományi Kar, debrenti@gmail.com
}

\begin{abstract}
Absztrakt. A különböző technológiáknak köszönhetően, mint például a nanotechnológia, a következő évtizedek teljesen átalakítják az egyes termelési folyamatokat, ágazatokat. Az információs technológia rohamos fejlődésének köszönhetően, az ipari folyamatok digitalizációja és automatizációja új kihívások elé állítja az élelmiszergazdasági szereplőket. A magyar élelmiszeripari vállalkozások akkor lesznek képesek lépést tartani versenytársaikkal és lesznek nyertesei a következő évtizedeknek, ha eredményesen tudják adaptálni ezeket a technológiákat. Ehhez azonban arra van szükség, hogy kiemelten foglalkozzanak a digitalizációval, a digitális stratégiával úgy, hogy a beruházásokat, a technológiaváltásokat és a kutatási-fejlesztési tevékenységet ebbe az irányba tereljék. A digitalizáció a jövő egyik meghatározó iránya, éppen ezért éreztem fontosnak, hogy egy kutatás során vizsgáljam a magyarországi élelmiszeripari vállalkozások digitalizációjának szintjét, az informatikai infrastruktúrát és Internet használatot, a vállalatirányítási rendszerek, a döntéstámogató és üzleti elemző eszközök használatát és szerepét, valamint a vállalkozások felkészültségét az Ipar 4.0 technológiai váltással kapcsolatban. A kérdőívre adott 205 értékelhetố válasz alapján elmondható, hogy a válaszadó magyar élelmiszeripari vállalkozásoknak csak igen kis hányada rendelkezik digitális stratégiával és csak kevés az olyan vállalkozás ahol van olyan személy, akinek a feladatkörébe tartozik a digitális átalakítás.
\end{abstract}

Kulcsszavak: digitalizáció, élelmiszer-feldolgozó ágazat, ipar 4.0

Abstract. Thanks to various technologies, such as nanotechnology, the next decades will completely transform the individual production processes and sectors. With the rapid advancement of information technology, the digitalization and automation of industrial processes pose new challenges for food business operators. Hungarian food companies will be able to keep up with their competitors and be the winners for the next decades if they can successfully adopt these technologies. However, this requires a strong focus on digitization, digital strategy, and directing investment, technology change and R\&D activities in this direction. Digitization is one of the decisive directions of the future, which is why I felt it essential to study the level of digitization of Hungarian food companies, IT infrastructure and Internet usage, the use, and role of enterprise management systems, decision support and business analysis tools, and business readiness, Industry 4.0 technology change. Based on the 205 evaluable responses to the questionnaire, it can be said that only a tiny proportion of Hungarian food companies have a digital strategy and only a few have digital transformation.

Keywords: digitalization. food-processing sector, Industry 4.0 


\section{Bevezetés}

Az elmúlt években a gyártó vállalatok különféle kihívásokkal szembesültek: az ingadozó kereslettel és a változó igényekkel az ügyfelek, valamint a szállítók részéről. Ez a tendencia közvetlen hatással van az értékláncra (Burger et al., 2017). Ezen kihívások leküzdése érdekében a vállalkozások a gyártási folyamatok digitalizációja és automatizációja irányába fordultak, mely tulajdonképpen az Ipar 4.0 alapját jelenti. A cél nem más mint a gyorsan fejlődő IKT1ㅜ folyamatos hatásából származó magas innovációs és gazdasági potenciál kiaknázása (Anderl, 2015).

Az Ipar 4.0-t 2011-ben a német kormány kezdeményezése alkotta, egyetemek és magánvállalkozások közreműködésével. Stratégiai program volt a fejlett termelési rendszerek fejlesztésére, a nemzeti ipar termelékenységének és hatékonyságának növelése céljából (Kagermann et al., 2013).

A digitális átalakulás különféle dimenzióin belül felhívták a politikai döntéshozók, tudósok és vezetők figyelmét: a digitalizálásnak a gyártási folyamatokhoz történő alkalmazásából adódó lehetőségekre, melyeket ma általánosan a Ipar 4.0-nak hívnak (Smit et al., 2016).

Az Ipar 4.0 egy összetett és rugalmas rendszer, amely számos kihívást és lehetőséget kínál, például az új technológiák bevezetése és integrálása a minőség, a hatékonyság és a versenyképesség javítása érdekében. Ez jelenleg a legtöbb vállalkozás jövőképe (Demartini et al., 2018).

A termelési érték tekintetében az élelmiszeripar Magyarországon a harmadik legnagyobb, az első a magyarországi munkavállalók száma és az első a feldolgozóiparban Európában, valamint az erőforrások jelentős felhasználója. Ezért rendkívül fontos az élelmiszeripar termelékenységének és hatékonyságának növelése az Ipari 4.0 alkalmazásokkal, valamint a digitalizálás számos új lehetőségével. Ily módon új termékeket, új szolgáltatásokat, új megoldásokat és megközelítéseket lehet fejleszteni az erőforrások jobb felhasználására, a minőségi paraméterek javítására, új készségek és kompetenciák létrehozására.

Nem kérdés, hogy az élelmiszeriparban is rendkívül fontos az innováció, a technológiaváltás és a digitalizáció erősítése. A kormány által elfogadott, a 2017-2050 közötti időszakra vonatkozó élelmiszergazdasági koncepció ${ }^{2}$ ráadásul kiemelten kezeli az élelmiszeripar fejlesztését.

A termelés, a termelési környezet pontos, adatszerű megismerése, adatok gyűjtése, adatbázisok építése, automatikus beavatkozásokat és döntéseket támogató alkalmazások fejlesztése és mindezen eszközök integrálása, a digitalizáció a jövő egyik meghatározó iránya, hiszen a jövő élelmiszergazdasága információra és tudásra épül.

A digitális átalakulás hatással van az üzleti modellekre, a termelési folyamatokra és a vállalatirányításra. Az információs és kommunikációs technológiák (IKT) infrastruktúrájának és az analitikai képességek fejlesztése az elmúlt évtizedben az innováció folyamát támogatta az üzleti modellek minden szintjén (Grover et al., 2013; Bleicher et al., 2016). A digitális átalakítás területe azonban hatalmas, és annak

\footnotetext{
${ }^{1}$ információs és kommunikációs technológia

${ }^{2}$ https://www.kormany.hu/download/0/07/11000/\%C3\%89lelmiszergazdas\%C3\%A1gi\%20Program\%202017-2050.pdf 197
} 
mértékét több elem kombinációja eredményezi: a vállalkozás információs rendszerének (IT) erőforrásai (Ashrafi et al., 2015), az ipari környezet (Mithas et al., 2013) és a közpolitikák (GTAI, 2013).

Napjaink gyorsuló ipari fejlődése magával hozza a vezetői döntések átalakulását: ma már nincs döntés a digitalizáció nélkül. A döntéstámogató rendszerek (Decision Support Systems - DSS³) típusai és eszköztára széleskörű. A DSS egy informatikai rendszer, amely támogatja a döntéshozatalt. Amikor döntést hozunk, alternatívákat választunk. Támogatja az alternatívák készítését, értékelését és / vagy összehasonlítását, így segít abban, hogy a helyes döntést hozzuk meg (Alter, 1980).

Wu szerint az üzleti intelligencia (Business Intelligence - BI) a DSS utódja. Cikkében azt írja, hogy a DSSalkalmazások új generációja BI rendszerekké fejlődött (Wu, 2000). Loshin (2012) szerint a BI magában foglalja az adattárházakat, az üzleti elemzési eszközöket és a tudásmenedzsmentet. Ebben a megfogalmazásban a szerző az üzleti intelligenciát folyamatnak tekinti, ahol az adatokból információkat generál, és az információk alapján tud döntést hozni (Loshin, 2012). Elterjedése előtt hazánkban főleg döntéstámogató rendszereknek neveztük a ma üzleti intelligencia rendszereknek hívott rendszereket, vagy használtuk a vezetői információs rendszer, az OLAP, az adattárház és az adatbányászat szakszavakat az átfogó üzleti intelligencia kifejezés helyett.

A tervezett magyar digitalizációs stratégia a teljes élelmiszer-gazdaságra összpontosít a nyersanyagtermelés láncától a végső fogyasztóig, az ipari élelmiszer-feldolgozás kérdéseivel. Jelenleg ez a magyar élelmiszeripar területe, ahol a lehető leghamarabb megoldást kell találni a termelékenység, az erőforráshatékonyság, a munkaerőhiány, a szakképzettség hiánya és a leggyorsabb, kézzelfogható előnyökkel járó problémákra.

Ma a menedzsment támogatási rendszerek és eszközök széles skálája áll rendelkezésre a vállalat hatékony működéséhez. E rendszerek alkalmazásának előfeltétele a vállalkozások megfelelő digitalizálása és digitális készenléti képessége.

Ebben a cikkben a vezetői döntések támogatására szolgáló technológiák legfontosabb funkcióit, jellemzőit és szempontjait vizsgáltam: hálózati infrastruktúra és internethasználat; integrált vállalati információs rendszerek (ERP) használata; információs rendszerek (MIS); vélemények az üzleti intelligenciaeszközök (BI) és az ipari 4.0 néhány legfontosabb információs technológiájáról.

A vizsgálat főbb célkitűzései az alábbiak:

- A magyar élelmiszeripar strukturája és digitalizáció összefüggései

- A döntéstámogató rendszerek fejlődése - tendenciák feltárása

- Alkalmazások helyzetének feltárása

- Az alkalmazások szélesebb elterjedését gátló fontosabb tényezők elemzése.

A vizsgálathoz megfogalmazott hipotézisek a következők:

1. hipotézis: Az élelmiszer-feldolgozó vállalkozások számára is nélkülözhetetlen az információs és kommunikációs eszközök használata, de ezek mértéke jelentősen függ a vállalkozás méretétől.

\footnotetext{
${ }^{3}$ DSS (Decision Support Systems) = döntéstámogató rendszer
} 
2. hipotézis: Az integrált vállalatirányítási információs rendszerek (ERP) használata jelentős mértékben függ a vállalati mérettől.

3. hipotézis: A vezetői információs rendszerek és üzleti intelligencia eszközök általában csak a nagyobb vállalkozások esetén kerül alkalmazásra. A teljes ágazat esetén ez rendkívül alacsony mértékű.

4. hipotézis: A vállalkozások többsége nem foglalkozik a digitalizáció és integráció kérdésével, melyeknek a jelenlegi szintje ebből kifolyólag alacsony. A válaszadók nem remélnek jelentős árbevétel növekedést a digitalizálástól.

\section{Anyag és módszer}

A kutatási cél részben meghatározta azokat a kutatási módszereket, eszközöket, amelyeket a vizsgálatba célszerű volt alkalmazni. A kutatás során (2019-ben) az informatikai eszköz ellátottság, az integrált vállalati információ rendszerek (ERP) döntéstámogatásbeli szerepét és kapcsolatát, az üzleti elemzési eszközök (BI) használatát és az Ipar 4.0-t támogató technológákkal kapcsolatos vállalati véleményeket vizsgáltam.

\subsection{A kérdőíves felmérés fontosabb jellemzői}

A felmérés anonim on-line kérdőíves formában történt. Az első fázisban az irodalom tanulmányozását követően, megterveztem a tartalmat, a kérdőív kérdéscsoportjait és magukat a kérdéseket. Ezután a második fázisban a kérdőíves on-line rendszer kiválasztása, a kérdések és válaszlehetőségek bevitele után véleményezés céljából kiküldésre került vállalati szakembereknek, illetve a Nemzeti Agrárgazdasági Kamara (NAK) és az Agrárgazdasági Kutató Intézet (AKI) részére.

A kapott javaslatok alapján, megtörtént a kérdőív véglegesítése, melyet a harmadik fázisban (2019 április-május hónapokban), egy előzetesen létrehozott levelezési listán a vállalkozások részére kiküldtünk, illetve közzétettünk a NAK és az AKI honlapján. A haladás ellenőrzése minden hét elteltével megtörtént, így egy hónap után célszerűnek láttuk meghosszabbítani a kérdőívet további egy hónappal. A kérdőív leállítása és az adattisztítás után kezdődött a kérdésekre adott válaszok alapján a statisztikai kiértékelés. Az egyszerű statisztikai táblák és grafikonokokon kívül, az adatok vállalati méretkategória és ágazat alapján is elemzésre kerültek.

\subsection{A kérdőív kérdéscsoportjai}

A kérdéscsoportok és tartalmuk az alábbiak voltak:

- I. Általános vállalati információk (földrajzi elhelyezkedés, iparág, tulajdonosi forma, méret, jogi forma, nettó értékesítés)

- II. IT-infrastruktúra és internethasználat (IKT-eszközök és számítógépes hálózat, internethozzáférés, weboldalhasználat, felhőalapú szolgáltatások)

- III. Vállalati információs rendszerek (ERP) (müködési forma, végrehajtás, használat, támogatott tevékenységek, elégedettség) 
- IV. Vezetői információs rendszerek (VIR használata (az alkalmazás végrehajtása, igények, elvárások, előnyök, ki és mihez használják?)

- V. Business Analytics (BI) eszközök használata (üzleti elemzési technológiák, alkalmazott területek, előnyök, jövőbeni felhasználás)

- VI. Ipar 4.0 (digitális technológiák, digitalizálás (jelen-jövő), befektetések, előnyök)

A fenti kérdéscsoportokon belül a következő kérdés típusokat használtam: Igen / Nem, Lista (rádió), Többszörös választás, Mátrix (5 pont választás), Dátum / Idő, Mátrix (Igen / Nem / Nem biztos), Mátrix kettős skála, Rövid szabad szöveg.

\section{Vizsgálati eredmények és azok értékelése}

\subsection{Reprezentativitás}

A vizsgált sokaságot a magyarországi élelmiszerfeldolgozó vállalkozások képezték. A vizsgálatnál törekedtem a reprezentatív minta elérésére. Mivel a felkérés minden vállalkozáshoz eljutott a teljes sokaságból a válaszadók véletlenszerüen kerültek ki, minden mintavételezési egységnek ugyanannyi esélye volt a válaszadásra (a mintába kerülésre).

A minta kiválasztásának általános követelménye, hogy a minta reprezentálja a vizsgált szempont szerint azt az alapsokaságot, amiből vettük, vagyis jól tükrözzze az alapsokaság összetételét és jellemzőit. A cél az volt, hogy a mintasokaság a valóságnak megfelelően tükrözze az alapsokaság tulajdonságait. A minta nagyságát és a reprezentativítás mértékét az alábbi táblázat mutatja.

\begin{tabular}{|r|l|r|r|r|}
\hline $\begin{array}{c}\text { Ág- } \\
\text { kód }\end{array}$ & \multicolumn{1}{|c|}{$\begin{array}{c}\text { Vállalkazások } \\
\text { száma } \\
\text { (A) }\end{array}$} & $\begin{array}{c}\text { Minta } \\
\text { (Válaszadók száma) } \\
\text { (B) }\end{array}$ & $\begin{array}{c}\text { Százalék } \\
\text { (B/A) }\end{array}$ \\
\hline 101 & Húsipar & 500 & 38 & $8 \%$ \\
\hline 102 & Halfeldolgozás & 30 & 2 & $7 \%$ \\
\hline 103 & Gyümölcs- és zöldségfeldolgozás & 500 & 27 & $5 \%$ \\
\hline 104 & Növényi, állati olaj gyártása & 60 & 7 & $12 \%$ \\
\hline 105 & Tejfeldolgozás & 100 & 11 & $11 \%$ \\
\hline 106 & Malomipari termékek gyártása & 100 & 10 & $10 \%$ \\
\hline 107 & Pékáru, tésztafélék gyártása & 1200 & 36 & $3 \%$ \\
\hline 108 & Egyéb élelmiszer gyártása & 600 & 44 & $7 \%$ \\
\hline 109 & Takarmány gyártása & 100 & 12 & $12 \%$ \\
\hline 110 & Italgyártás & 1400 & 33 & $2 \%$ \\
\hline 120 & Dohánytermék gyártása & 10 & 1 & $10 \%$ \\
\hline & \multicolumn{1}{|c|}{ Összesen } & $\mathbf{4 6 0 0}$ & $\mathbf{2 2 1}$ & $\mathbf{5 \%}$ \\
\hline
\end{tabular}

1. táblázat. A minta nagysága az ágazatok szerinti megoszlásban (N=205).

\subsection{A válaszadó vállalkozások jellemzői}

A kutatásban részt vevő vállalatok székhely szerinti megoszlása a következő: 12\%-a Pest megyei székhelyű, így a közép-magyarországi régióból kerül ki a cégek $12 \%$-a; a dunántúli régiókból a részvétel 
41\%-os, míg az észak-magyarországi, észak-alföldi és dél-alföldi régiókból összesen 47\% a mintában lévő cégek aránya. A válaszadók regionális eloszlása azt mutatja, hogy a kutatási kérdőív kitöltésére, a dél-dunántúli régióból vállalkoztak a legkevesebben (2. táblázat).

\begin{tabular}{|l|r|r|r|r|r|}
\hline \multicolumn{1}{|c|}{$\begin{array}{c}\text { Régió / } \\
\text { Vállalati méret }\end{array}$} & Mikro- & Kis- & Közép- & Nagy- & $\begin{array}{c}\text { Válaszadók } \\
\text { száma }\end{array}$ \\
\hline Észak-Magyarország & 9 & 9 & 6 & 1 & 25 \\
\hline Észak-Alföld & 6 & 17 & 10 & 1 & 34 \\
\hline Dél-Alföld & 13 & 13 & 5 & 6 & 37 \\
\hline Közép-Magyarország & 8 & 12 & 1 & 4 & 25 \\
\hline Közép-Dunántúl & 8 & 19 & 6 & 1 & 34 \\
\hline Nyugat-Dunántúl & 10 & 9 & 7 & 2 & 28 \\
\hline Dél-Dunántúl & 11 & 8 & 3 & 0 & 22 \\
\hline \multicolumn{1}{|c|}{ Összesen } & $\mathbf{6 5}$ & $\mathbf{8 7}$ & $\mathbf{3 8}$ & $\mathbf{1 5}$ & $\mathbf{2 0 5}$ \\
\hline \multicolumn{1}{|c|}{$\%$} & $\mathbf{3 2 \%}$ & $\mathbf{4 2 \%}$ & $\mathbf{1 9 \%}$ & $\mathbf{7 \%}$ & $\mathbf{1 0 0 \%}$ \\
\hline
\end{tabular}

2. táblázat. A kérdőivet kitöltők megyénként/régiónkéni és vállalati méret szerinti megoszlása (N=205).

A vállalkozások méret szerinti besorolásánál a kis- és középvállalkozásokról, fejlődésük támogatásáról szóló 2004. évi XXXIV. törvényt vettem figyelembe. Így a statisztikai lehatárolás a létszám-kategória és az éves nettó árbevétel alapján történt. Ennek tekintetében a kisvállalkozások aránya a legjelentősebb (42\%), ugyanakkor az is megfigyelhető, hogy a válaszadók 93 százaléka KKV és mikro-vállalkozás, míg 7 százalékuk nagyvállalkozás.

Tevékenységi kör szerinti megoszlásban a legtöbb vállalkozás az „Egyéb élelmiszer gyártása” ágazatba esik, majd az ezt követő leggyakoribb ágazatok a Húsfeldolgozás, -tartósítás, húskészítmények gyártása, illetve a Pékáru, tésztafélék gyártása (1. ábra).

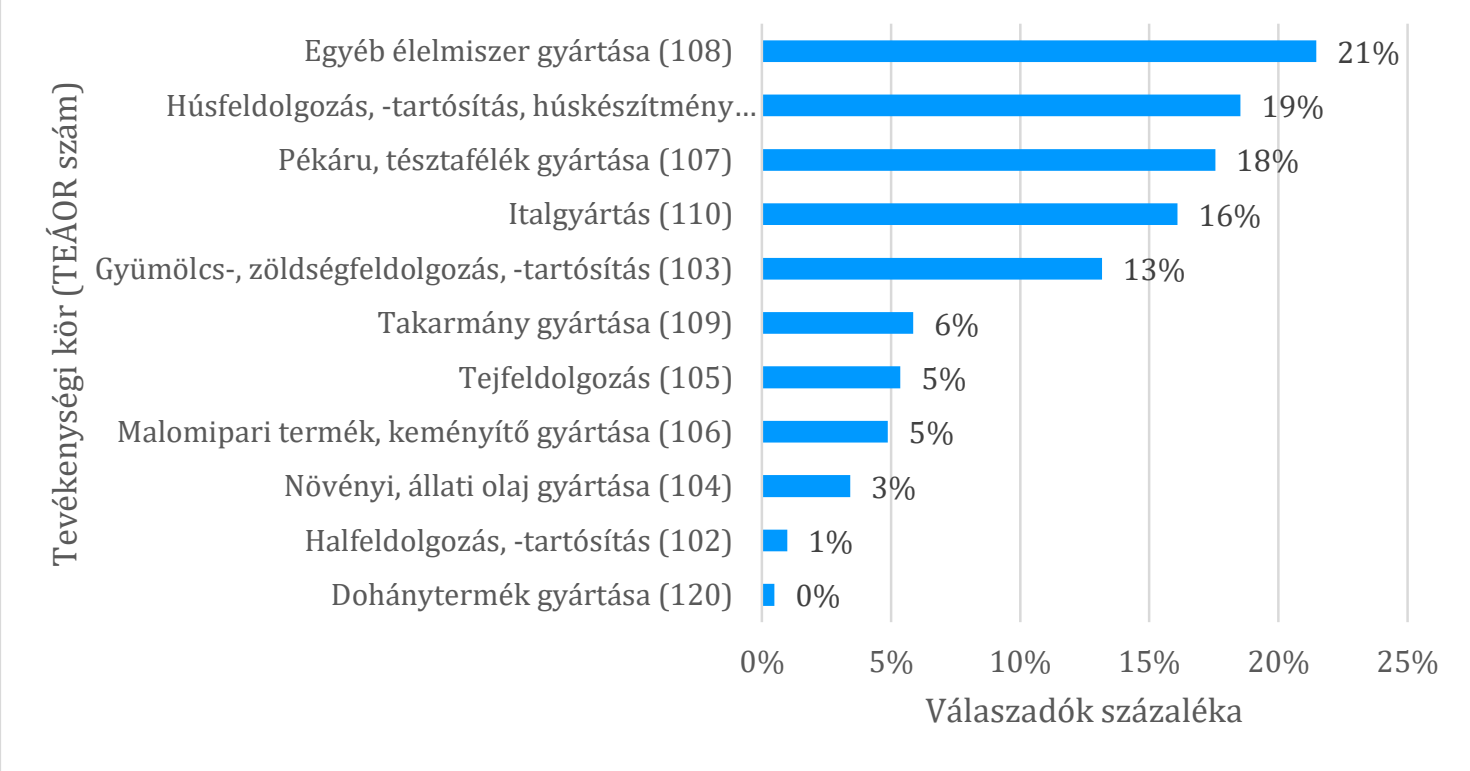

1. ábra. A válaszadó vállalkozások megoszlása tevékenységi kör szerint ( $N=205)$. 


\subsection{A digitalizációs helyzet néhány indikátora}

Ma már szinte kulcstényező, hogy egy vállalkozásban működjön vállalati lokális számítógép hálózat. Ennek ellenére a válaszadó magyar élelmiszerfeldolgozó vállalkozások esetében megközelítőleg felefele arányban működik, illetve nem működik belső számítógép hálózat. Integrált vagy önálló vállalatirányítási rendszerrel a vizsgált vállalkozások csak 31 százaléka rendelkezik, 10-ből 7 vállalkozás nem vezetett be ERP rendszert. Ennél is kevesebben, a felméréshez csatlakozók mindössze 10 százalékánál működik vezetői információs rendszer illetve ugyanilyen arányban használnak üzleti elemző eszközöket (2. ábra).

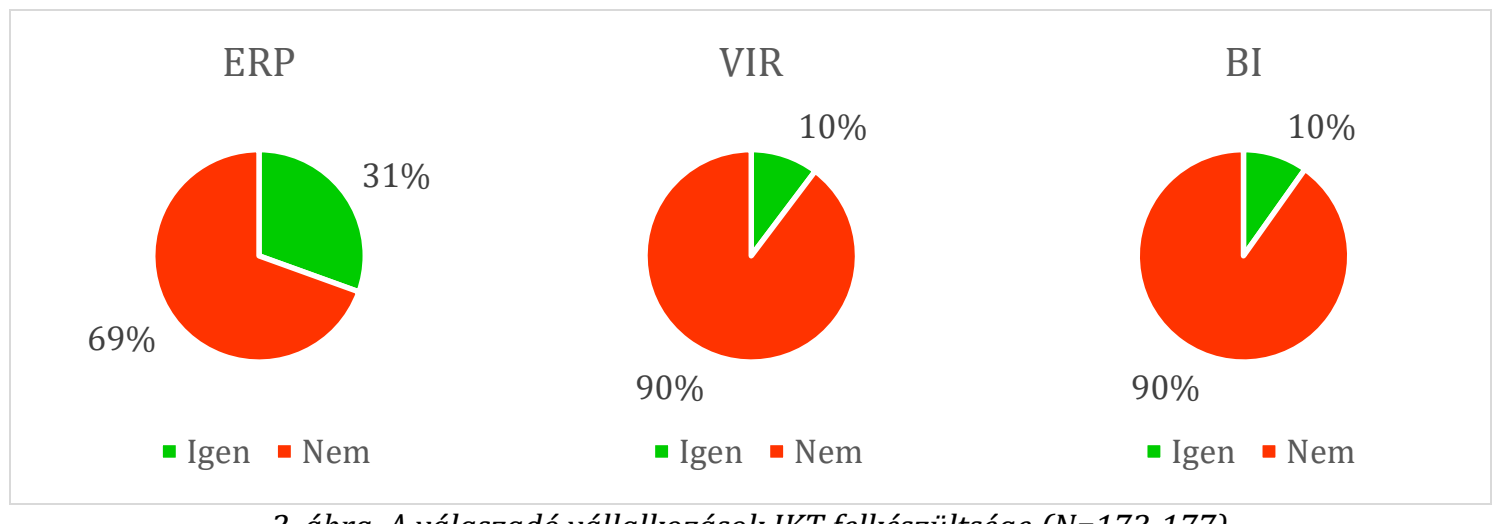

2. ábra. A válaszadó vállalkozások IKT felkészültsége (N=173-177)

\subsection{Informatikai infrastruktúra}

Ma már elképzelhetetlen, hogy egy vállalkozás ne használjon valamilyen számítógépet, informatikai eszközt a vállalkozás irányításában, a vállalkozások menedzselésében, információk (adatok) gyüjtésében, feldolgozásában, stb. A helyzetfelmérés során az általam 3. táblázatban felsorolt fontosabbnak ítélt eszközök használatára kérdeztem rá. A legelterjedtebb információs és kommunikációs eszköz az asztali számítógép, a vállalkozások 84\%-a használ ilyet, azonban hordozható eszközöket még csak 61-66 százalékuk használ. Az, hogy nem minden vállalkozás használ asztali személyi számítógépet, a hordozható eszközök egyre nagyobb elterjedésének köszönhető. Szerverrel csak a válaszadók 42\%-a rendelkezik, míg felhő alapú szolgáltatást csak 10-ből három vállalkozás vesz igénybe. Ennél is kevesebb (9\%), az ipari tábla PC-t használók aránya. Az ipari tábla PC (tablet) használata a közvetlen termeléshez, a munkafolyamatok menedzselésében használatos, ez feltételezhetően ágazatfüggő. 


\begin{tabular}{|l|r|r|r|r|r|}
\hline \multicolumn{1}{|c|}{$\begin{array}{c}\text { IKT eszközök / } \\
\text { Vállalati méret }\end{array}$} & \multicolumn{1}{c|}{ Mikro- } & \multicolumn{1}{c|}{ Kis- } & \multicolumn{1}{c|}{ Közép- } & Nagy- & $\begin{array}{c}\text { Összes } \\
\text { vállalkozás }\end{array}$ \\
\hline Asztali számítógépek & $73 \%$ & $90 \%$ & $83 \%$ & $100 \%$ & $84 \%$ \\
\hline Laptopok, notebookok & $55 \%$ & $66 \%$ & $77 \%$ & $92 \%$ & $66 \%$ \\
\hline Tablet, okostelefon & $53 \%$ & $60 \%$ & $69 \%$ & $85 \%$ & $61 \%$ \\
\hline Ipari tábla PC & $0 \%$ & $2 \%$ & $20 \%$ & $62 \%$ & $9 \%$ \\
\hline Szerver(ek) & $6 \%$ & $43 \%$ & $83 \%$ & $100 \%$ & $42 \%$ \\
\hline Felhő alapú szolgáltatás & $19 \%$ & $30 \%$ & $34 \%$ & $62 \%$ & $30 \%$ \\
\hline
\end{tabular}

3. táblázat. IKT eszközök használatának aránya a válaszadók vállalati méret szerinti megoszlásának függvényében $(N=192)$

A nagyvállalkozások minden információs és kommunikációs eszköz használata terén az élvonalban járnak, mindegyikük használ asztali számítógépeket és szervereket. Ezt követően a legtöbbek által használt eszközök a mobil eszközök és ennél is kevesebb vállalkozás használ ipari tabletet és felhő alapú szolgáltatásokat.

Igazi nagy különbségeket az ipari tablet, szerverek és a felhő alapú szolgáltatások esetében láthatunk. A mikrovállalkozások sereghajtók minden tekintetben. Érthető módon nem használnak ipari tabletet, és csupán 6\%-a az ebbe a kategóriába tartozó vállalkozásoknak alkalmaz szervereket, felhő alapú szolgáltatásokat viszont háromszor többen. Az asztali számítógépeket leszámítva, minden esetben elmondható, hogy a vállalati méret növekedésével ezen eszközöknek a használata is népszerűbb.

Az első hipotézisem teljesült, mivel az előzőek alapján egyértelműen megfogalmazható, hogy az élelmiszerfeldolgzó vállalkozások nagy mértékben használnak információs és kommunikációs eszközöket, és ezek használatának mértéke függ a vállalkozás méretétől.

\subsection{Vállalati döntéstámogatás}

\subsubsection{ERP a menedzsment támogatásában}

Integrált vagy önálló vállalatirányítási rendszerrel a vizsgált vállalkozások 69 százaléka nem rendelkezik. Pedig egy vállalatirányítási rendszer lehetővé teszi a szervezeti folyamatok és adatok kezelését a vállalat különböző működési területein.

A válaszok alapján megállapítható, hogy a nagyvállalkozások mindegyike használ integrált vállalatirányítási információs rendszert, míg a KKV-k 32-66 százaléka rendelkezik ERP-vel, a mikrovállalkozások esetében pedig nem beszélhetünk ERP használatról (3. ábra). 


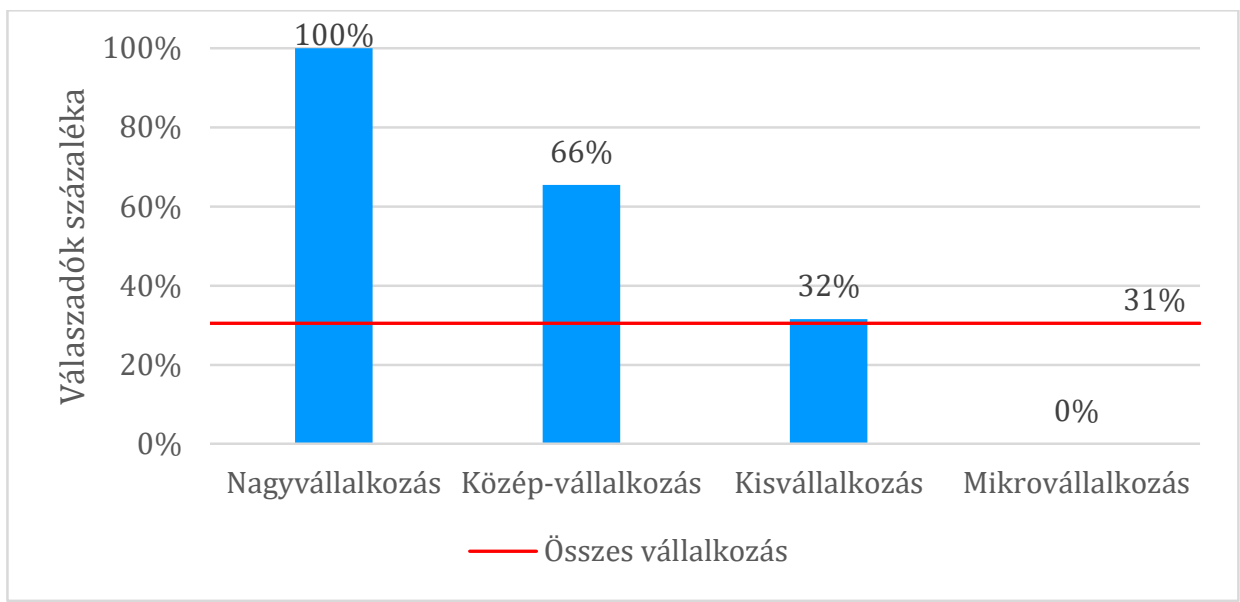

3. ábra. ERP-t használók aránya méretkategórián belül $(N=54)$

A második hipotézis is egyértelműen teljesült, miszerint az integrált vállalatirányítási információs rendszerek (ERP) használata jelentős mértékben függ a vállalati mérettől. Minden nagyvállalkozás működtet ilyen rendszert, míg a középvállalkozásoknak csak kétharmada és a kisvállalkozásoknak csak egyharmada, a mikrovállalkozások pedig nem használnak ERP rendszert.

A felmérésben részt vevők több mind két harmada nem használ ERP rendszert. Ennek okait vizsgálva a feltett kérdésekre kapott válaszok alapján a legtöbb válaszadó szerint a vállalat mérete nem indokolja a bevezetést (76\%), a második leggyakrabban választott ok az, hogy a vállalkozás pénzügyi lehetőségei nem teszik lehetővé az ERP használatot (22\%) és csak 11 százalékuk gondolja úgy, hogy a felsővezetés részéről nincs meg az igény a rendszer bevezetésére.

Megvizsgálva az okokat vállalati méret szerinti lebontásban, láthatjuk, hogy a mikro- és kisvállalkozások esetén úgy ítélték a legtöbben, hogy a vállalat mérete nem indokolja a bevezetést (4. ábra). A mikrovállalkozások 97\%-a jelölte ezt meg, míg a kisvállalkozások kategóriában tevékenykedő válaszadók 62\%-a. Ez utóbbi méretkategóriában a vállalkozások közel egyharmada úgy értékelte, hogy a pénzügyi lehetőségek nem teszik lehetővé a bevezetést. Ezt az okot jelölte meg 10-ből 3 középvállalkozás is. Habár ebben a vállalati méretben főként (50\%) a felsővezetői igény hiánya miatt nem működik ERP rendszer.

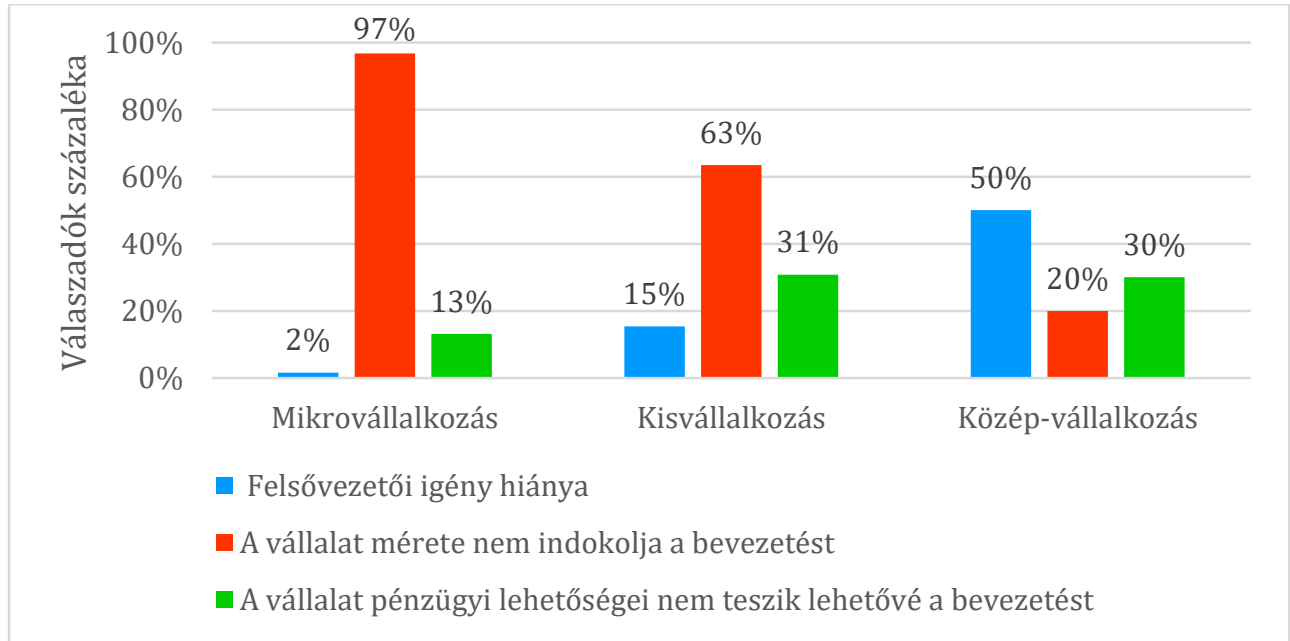

4. ábra. Okok, amiért egyes vállalkozásoknál nem múködik ERP rendszer, méretkategórián belül (N=123) 


\subsubsection{Vezetői információs rendszerek és üzleti intelligencia eszközök használata}

A vezetői információs rendszer a vállalat meglévő rendszereiből táplálkozó, speciális adatbáziskezelőre épített vállalati alkalmazás, mely a gyors válaszidő és az egyszerű kezelhetőség mellett biztosítja a menedzsment számára szükséges információkat. A felmérésben részt vevő vállalkozásoknak csak igen kis hányada, 10 százaléka rendelkezik ilyen rendszerrel.

Az 5. ábrán látható, hogy vezetői információs rendszert használók közül a nagyvállalkozások közel háromnegyede (73\%) használja. A vezetői információs rendszer jóval kisebb hangsúlyt kap a vállalati méret csökkenésével, középvállalkozásoknál 17\%, kisvállalkozásoknál 5\%, míg a mikrovállalkozások körében csak 2\%. Ha a VIR-t használó KKV-k arányát nézzük, akkor az átlag 6\%, ami elég alacsonynak tekinthető.

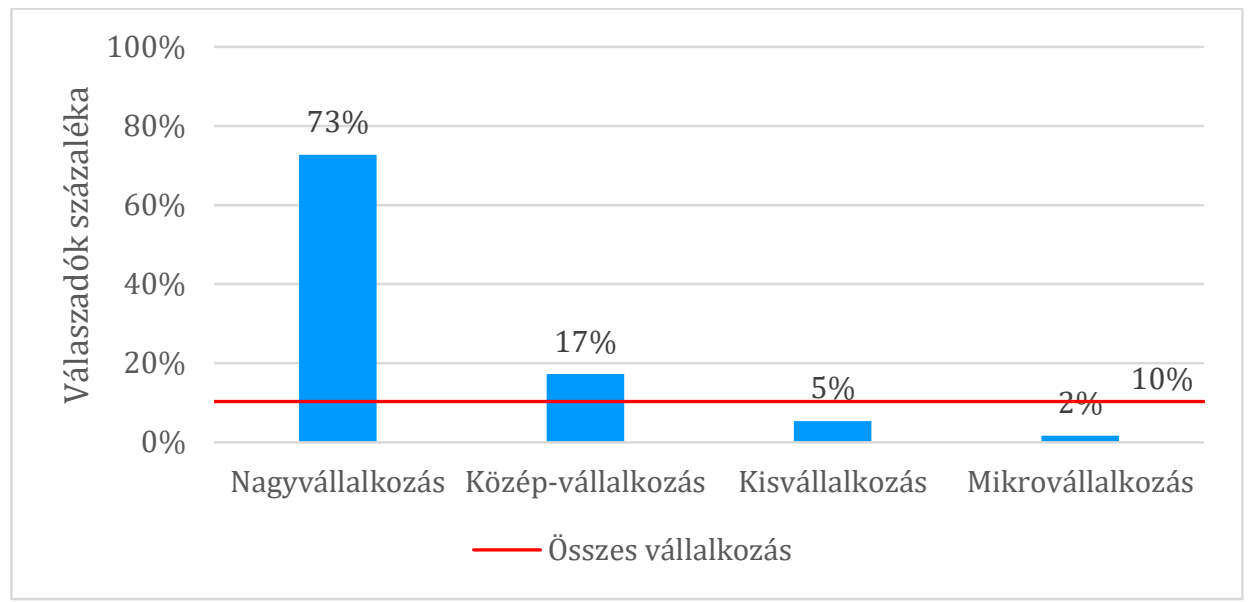

5. ábra. VIR-t használó válaszadók aránya, méretkategórián belül ( $N=18)$

Habár az üzleti intelligencia eszközök egyre szélesebb körben állnak rendelkezésre a vállalkozások számára, mégis a felméréshez csatlakozó élelmiszeripari vállalkozások közül csak 10 százalékuk használja ezeket.

\subsection{Az Ipar 4.0-ra vonatkozó digitalizációs technológiák és a vállalkozások felkészültségének néhány jellemzője}

Az Ipar 4.0 kifejezés a negyedik ipari forradalomra utalva az információs technológia és az automatizálás egyre szorosabb összefonódását, illetve ezen keresztül a gyártási módszerek alapvető megváltozását elhozó időszak összefoglaló neve. Átformálja a teljes gyártási és ellátási láncot, ami komoly paradigmaváltást jelent az iparvállalatok számára stratégiájuk kialakításában.

Az Ipar 4.0 megvalósítása érdekében szükség van olyan eszközökre, amelyek az adatokat generálják, létrehozva ezzel a big datát. A kérdőív egy kérdése segítségével azt vizsgáltuk, hogy a különböző digitális eszközök és technológiák mennyire járulnak hozzá a megkérdezett vállalkozások digitalizációjához, az Ipar 4.0 koncepció fejlesztéséhez. A válaszdók szerint a legfontosabbnak ítélt technológiák ágazati arányait mutatja a 4. táblázat. 


\begin{tabular}{|c|c|c|c|c|c|}
\hline Ágazat / Digitális technológia & Mobil eszközök & $\begin{array}{c}\text { Helymeghatározási } \\
\text { technológiák } \\
\text { (GPS, GNSS) }\end{array}$ & $\begin{array}{c}\text { Felhő-alapú } \\
\text { számítástechnika }\end{array}$ & $\begin{array}{c}\text { Szenzor } \\
\text { technológia }\end{array}$ & $\begin{array}{l}\text { Digitális kamera } \\
\text { technológiák }\end{array}$ \\
\hline Húsipar & $75 \%$ & $36 \%$ & $21 \%$ & $39 \%$ & $25 \%$ \\
\hline Halfeldolgozás & $50 \%$ & $50 \%$ & $0 \%$ & $0 \%$ & $0 \%$ \\
\hline Gyümölcs- és zöldségfeldolgozás & $80 \%$ & $35 \%$ & $30 \%$ & $25 \%$ & $25 \%$ \\
\hline Növényi, állati olaj gyártása & $60 \%$ & $40 \%$ & $40 \%$ & $20 \%$ & $40 \%$ \\
\hline Tejfeldolgozás & $67 \%$ & $0 \%$ & $33 \%$ & $33 \%$ & $17 \%$ \\
\hline Malomipari termékek gyártása & $90 \%$ & $70 \%$ & $30 \%$ & $20 \%$ & $40 \%$ \\
\hline Pékáru, tésztafélék gyártása & $82 \%$ & $14 \%$ & $18 \%$ & $11 \%$ & $7 \%$ \\
\hline Egyéb élelmiszer gyártása & $71 \%$ & $24 \%$ & $38 \%$ & $21 \%$ & $15 \%$ \\
\hline Takarmány gyártása & $57 \%$ & $57 \%$ & $57 \%$ & $57 \%$ & $29 \%$ \\
\hline Italgyártás & $79 \%$ & $38 \%$ & $41 \%$ & $41 \%$ & $14 \%$ \\
\hline Dohánytermék gyártása & $0 \%$ & $0 \%$ & $0 \%$ & $100 \%$ & $0 \%$ \\
\hline
\end{tabular}

4. táblázat. Legfontosabbnak ítélt technológiák ágazati arányai (N=192)

A következő ábrán a digitalizálás és az integráció jelenlegi és jövőbeli szintjét vizsgáltam, megfigyelhető, hogy egyik vállalati területen sem mondhatjuk magasnak a digitalizáció és integráció jelenlegi szintjét, viszont a válaszadók nagyon optimisták ami a várokozásokat illeti. A következő 2-3 évben minden területen javulásra számítanak, ami a digitalizálás és integráció szintjét illeti.

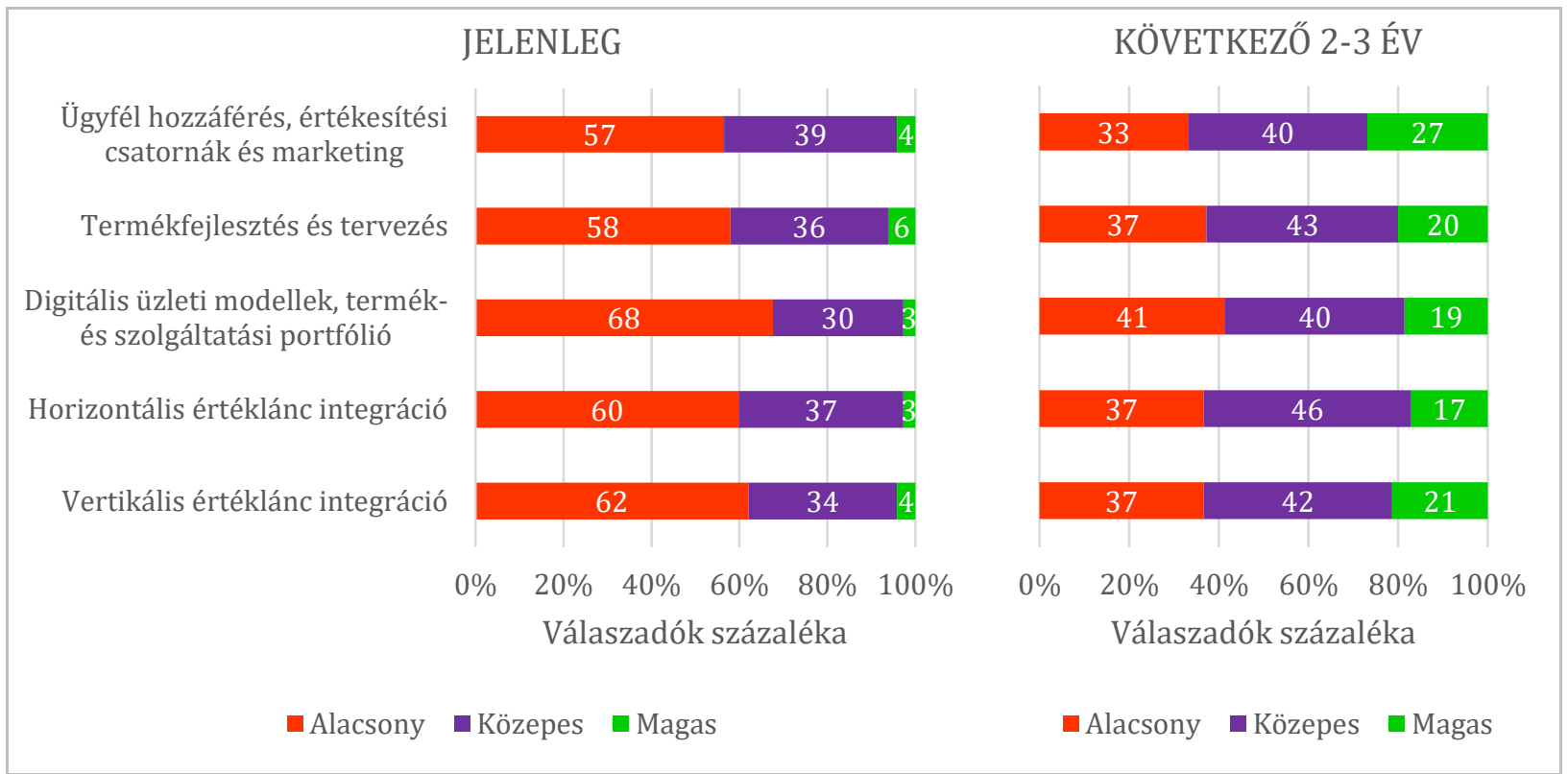

6. ábra. A digitalizálás és az integráció jelenlegi és várható szintje a vállalat különböző területein (N=145)

A vertikális integráció, elsődlegesen az ellátási láncban, később az ellátási hálózatban együttműködő partnerekkel való együttműködést, digitális összeköttetést foglalja magába. A jövőben, a válaszadók 21 százalékának becslése alapján a vertikális integráció magas szinten lesz. A jelenleg alacsony szintű integrációval rendelkező vállalkozásoknak több mint egy harmada remél vagy tervez magasabb szintű integrációt.

A horizontális integráció, a vállalaton belüli tevékenységi területek szoros, real-time összeköttetését és együttmúködését jelenti. Ebben az esetben is hasonló a helyzet, az integráció szintjének javulását reméli/tervezi a vállalkozások nagy hányada.

147 válaszadó vállalkozás közül csak 11 százalékuk rendelkezik digitális stratégiával (7. ábra), ami nem túl jó arány, ha napjaink digitális eszközeinek és technológiáinak térhódítására gondolunk. Ezen a 
területen a vállalkozásoknak még további fejlesztésekre van szüksége, ehhez azonban elengedhetetlen, hogy a stratégiaalkotás során figyelembe vegyék a digitalizáció hatásait és lehetőségeit.

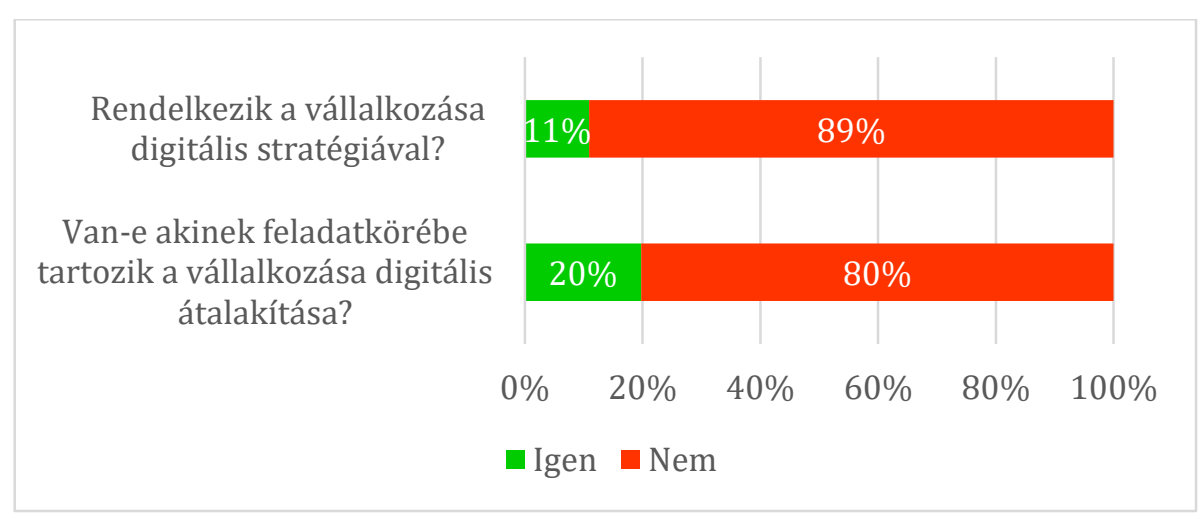

7. ábra. Digitális stratégia és digitális átalakítás (N=147)

Pozitívumnak mondható, hogy a vállalkozások ötöde (20\%-a) foglalkozik a digitális átalakítás feladatával, vagyis van olyan személy ezen vállalkozásoknál akinek a feladatkörébe tartozik a digitális átalakítás.

A negyedik hipotézisem részben teljesül, mivel tíz vállalkozásból csak egy rendelkezik digitális stratégiával és csak minden ötödik vállalkozásnál van humán erőforrás a digitális átalakításra, valamint a digitalizáció és az integráció szintje saját bevallásuk alapján igen alacsony.

A digitális átalakítás nem oldható meg megfelelő digitális fejlesztések nélkül, a vállalati működés valamennyi területén. A múltbeli és jövőbeli beruházások mértékét is vizsgáltam, a felmérésben részt vevő vállalkozások segítségével.

A vállalkozás digitalizálásából származó előnyöket 1-5 skálán értékelhették a válaszadó vállalkozások (1-Semmilyen, 2-Kicsi, 3-Nem tudom, 4-Mérsékelt, 5-Jelentős). A válaszok alapján (8. ábra) a legjelentősebb előnyt a költségcsökkenés terén várják (18\%), habár nem sokkal van lemaradva a versenyképesség növekedés (17\%), munkaerő-hatékonyság növekedés $(17 \%)$ és a termelékenység növekedés (16\%). Legkevésbé számítanak jelentős bevétel növekedésre (12\%).

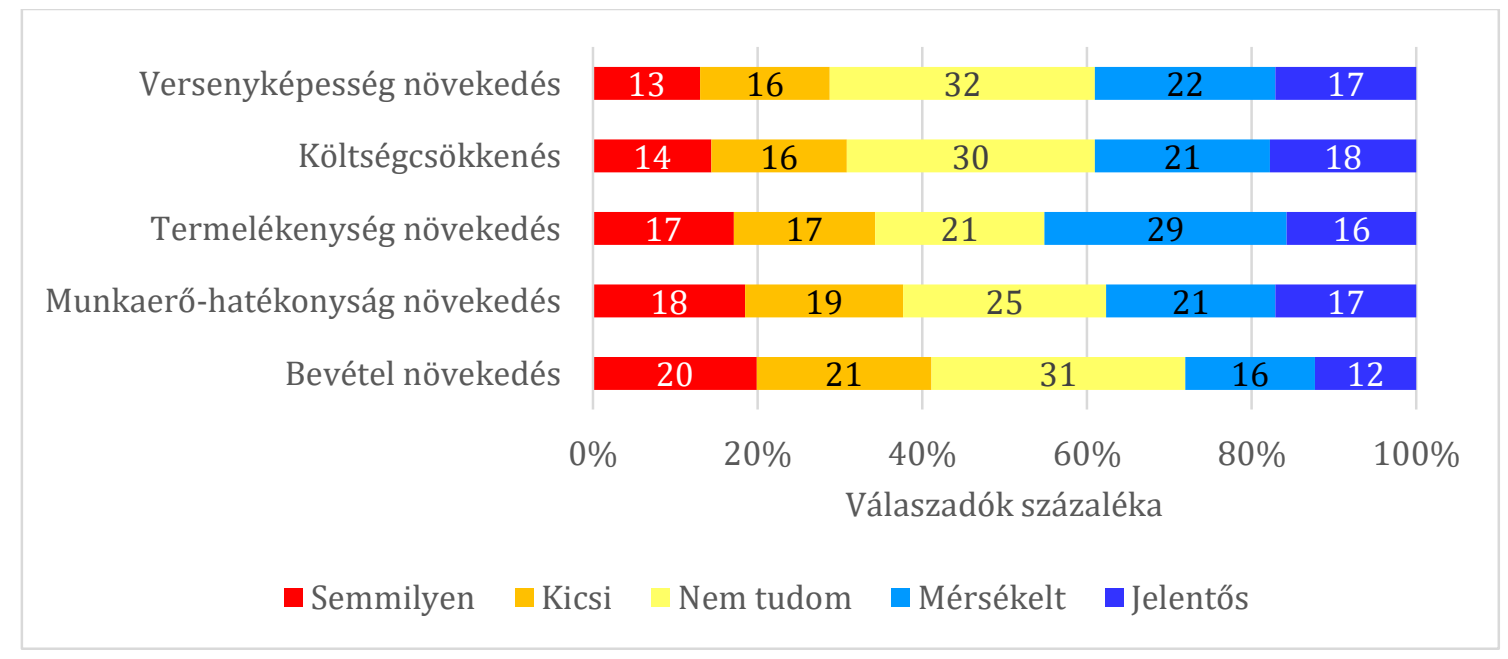

8. ábra. A digitalizálásból származó előnyök mértéke az elkövetkező 5 évben (N=146) 
Ha azt vizsgáljuk, hogy milyen területen számítanak bármilyen mértékű előnyre, akkor az első helyen a versenyképesség növekedés áll (a válaszadók 87\%-a számít valamilyen mértékű előnyre), ezt követi kevéssel lemaradva a költségcsökkenés (86\%). Viszont a bevétel növekedés ebben a megvilágításban is az utolsó helyre szorul (80\%). Ezek alapján a negyedik hipotézisem második fele is teljesülni látszik, miszerint a válaszadók nem remélnek jelentős árbevétel növekedést a digitalizálástól.

\section{Következtetések és javaslatok}

Az információ és kommunikációs eszközök használatának mértéke függ a vállalati mérettől. A mikrovállalkozások sereghajtók minden tekintetben. Nem használnak ipari tabletet, és csupán 7 százalékuk alkalmaz szervereket, felhő alapú szolgáltatásokat viszont háromszor többen. A nagyvállalkozások minden információs és kommunikációs eszköz használata terén az élvonalban járnak, a legkisebb népszerűségnek az ipari tablet és a felhő alapú szolgáltatások örvendenek.

A nagyvállalkozások mindegyike használ ERP rendszert, míg a KKV-k 32-66\%-a rendelkezik ERP-vel, a mikrovállalkozások esetében pedig nem beszélhetünk ERP használatról. A használat mértéke nő a vállalati méret növekedésével. A legmeghatározóbb ok, amiért egy vállalkozás nem rendelkezik ERP-vel az, hogy válallat mérete nem indokolja a bevezetést.

A vezetői információs rendszerek és üzleti intelligencia eszközök általában csak a nagyobb vállalkozások esetén kerül alkamazásra, a teljes ágazat esetén ez rendkivül alacsony mértékű (10\%).

A vállalkozások a jövőre nézve optimisták ami a digitalizációt és integrációt illeti, viszont csak kevesen rendelkeznek digitális stratégiával és a vizsgált vállalkozások 80 százalékánál nem is tartozik a feladatkörébe senkinek a vállalkozás digitális átalakítása. A vállalkozások digitális lemaradásban vannak és habár a digitalizáció és integráció jövőbeni szintjével kapcsolatosan optimisták, mégis legkevésbé számítanak jelentős bevételnövekedésre a digitalizálásból.

\section{Hivatkozások}

[1] S. Alter (1980), Decision Support System: current practice and continuing challenges, Addison-Wesley Pub

[2] R. Anderl (2015), Industrie 4.0-Technological Approaches, Use Cases, and Implementation, At-Automatisierungstechnik 63(10): 753-65.

[3] R. Ashrafi - J. Mueller (2015), Delineating IT resources and capabilities to obtain competitive advantage and improve firm performance, Inf. Syst. Manag. 32, 15-38, doi:http://dx.doi.org/10.1080/10580530.2015.983016.

[4] J. Bleicher - H. Stanley (2016), Digitization as a catalyst for business model innovation a three-step approach to facilitating economic success, J. Bus. Manag. 8, 62-71.

[5] N. Burger - M. Demartini - F. Tonelli - F. Bodendorf - C. Testa (2017), Investigating Flexibility as a Performance Dimension of a Manufacturing Value Modeling Methodology 
(MVMM): A Framework for Identifying Flexibility Types in Manufacturing Systems, Procedia CIRP.

[6] M. Demartini - C. Pinna - F. Tonelli - S. Terzi - C. Sansone - C. Testa (2018), Food industry digitalization: from challenges and trends to opportunities and solutions, IFAC PapersOnLine 51-11, 1371-1378.

[7] V. Grover - R. Kohli (2013), Revealing your hand: caveats in implementing digital business strategy, MIS Q. 37, 655-663.

[8] GTAI (2013), Industrie 4.0 Smart Manufacturing for the Future, doi:http://dx. doi.org/10.1007/978-3-642-36917-9.

[9] H. Kagerman - W. Wahlster - J. Helbig (2013), Securing the Future of German Manufacturing Industry Recommendations for Implementing the Strategic Initiative INDUSTRIE 4.0 Final Report of the Industrie 4.0 Working Group, doi:http://dx.doi.org/10.13140/RG.2.1.1205.8966.

[10] D. Loshin (2012), Business Intelligence: The Savvy Manager's Guide, Newnes.

[11] S. Mithas - A. Tafti - W. Mitchell (2013), How a firm's competitive environment and digital strategy posture influence digital business strategy, MIS Q. 37, 511-536, doi:http://dx.doi.org/10.1257/jel.50.4.1051.

[12] J. Smit - S. Kreutzer - C. Moeller - M. Carlberg, Industry 4.0 a Study for the European Parliament, http://www.europarl.europa.eu/studies.

[13] J. Wu (2000), Business Intelligence: What is Business Intelligence?, DM Review 